\title{
THE FACTORS WHICH ARE RELATED TO LEVEL ACCREDITATION IN THE PUBLIC HEALTH CENTER IN KONAWE DISTRICT
}

\author{
Isjan Harisal Liambo ${ }^{1}$, Tasnim Tasnim² ${ }^{2}$ Jasmurni Munir $^{3}$ \\ ${ }^{1,2,3}$ Faculty of Health Sciences, Universitas Mandala Waluya \\ Kendari, Southeast Sulawesi, Indonesia
}

Corresponding Author : Isjan Harisal Liambo

E-mail: isjan.harisal@gmail.com

\begin{abstract}
Background: Based on a preliminary survey conducted at a public and basic accredited health center by interviewing several staff at the health services, they said that the accredited Public health center had human resources in terms of quality and quantity, inadequate facilities and infrastructure. Also, administrative services was under standard operating procedures and it has not been carried out optimally. The quality of service has not met the standards as a service facility at the first level.

Methods: This study is an observational study which used a cross sectional approach. The sample in this study were 139 health workers. The analysis used chi square.

Result: There is a significant positive relationship between resources with the level of Public health center accreditation $(\mathrm{p}$-value $=0.000<0.05)$. There is a significant positive relationship between infrastructure and the level of accreditation ( $p$-value $=0.000<0.05)$. There is a significant positive relationship between service quality and accreditation level ( $\mathrm{p}$-value $=$ $0.005<0.05)$.
\end{abstract}

Conclusion: There is the relationship between resources, infrastructure, service quality and the level of Public health center accreditation.

Key words: Resources, Infrastructure, Service quality, Accreditation level 


\section{INTRODUCTION}

The success of health development plays an important role in improving the quality and competitiveness of Indonesia's human resources. To achieve the goal of national health development, various health efforts are carried out in a comprehensive, tiered and integrated manner(1). The need for changes in people's behavior must be in line with a better health development $\operatorname{program}(2)$.

Public health center are at the forefront of administering basic health efforts. Decree of the Minister of Health Number 75/2014 concerning "Community Health Centers", is the legal basis for administering Public health center(3).

Public health center accreditation has been carried out in stages since 2015 by the First Level Health Facility Accreditation Commission in 9,754 Public health center in Indonesia, with details of 3,396 Inpatient Public health center 6,358 Non-Inpatient Public health center. In terms of quantity, it can be seen that there are still some accredited Puskesmas in Konawe Regency whose human resources are not yet fulfilled, for example at the West Wonggeduku Public health center, general practitioners and dentists, the high rate of Respiration Tract Infection in the West Wonggeduku region inadequate facilities, for example dental care. Pondidaha Community Health Center which is middle accredited but there is no dentist and no medical technicality. and in Uepai Health Center, which has been accredited, there are no basic general practitioners and dentists(4).

From this data it also shows that accredited Public health center have not been able to meet the Public health center Accreditation Standard requirements stipulated in the Minister of Health of the Republic of Indonesia No. adequate. Based on this background, the researcher intends to conduct research with the title "faktors related to level accreditation in the public health center of konwe district"

\section{METHODS}

This quantitative of research is an observational analytic study with a cross sectional study design(9). The population was the measles vaccine which was found in 8 Puskesmas withThe sample size was 82 Vaccine for Measles.This research was carried out in all Puskesmas in Konawe Islands Regency in 2020.

\section{RESULTS}

Table 1 shows that the majority of respondents came from puskesmas with intermediate accreditation levels, namely 57 respondents $(41 \%)$ and the least respondents came from Public health center with nonaccreditation levels, namely 38 respondents (27.3\%)

Table 2 shows that 38 respondents who came from non-basic accreditation health centers, there were 38 respondents $(27.3 \%)$ who stated that the resources were inadequate and 44 respondents $(31.7 \%)$ at the basic accreditation level health centers stated that they were not sufficient. Of the 57 respondents (41\%) with an intermediate level of accreditation, $24(17.2 \%)$ stated that the resources were adequate and 33 respondents $(23.7 \%)$ stated that the resources were inadequate. Based on the results of statistical tests using the Chi Square test p-value $0.000 \leq 0.05$ This means that there is a significant relationship between resources and the level of accreditation at health centers in the Konawe Regency, Southeast Sulawesi Province.

Table 3 shows that 38 respondents who came from non-accredited health centers, there were 38 respondents $(27.3 \%)$ who stated that the infrastructure was inadequate and 44 respondents (31.7\%) with basic accreditation levels stated that the infrastructure was inadequate. Of the 57 $(41 \%)$ respondents who came from health centers with intermediate accreditation levels, 23 respondents $(16.5 \%)$ stated that they were inadequate and 34 (24.4\%) respondents stated that the facilities and infrastructure were adequate. Based on the 
Liambo, I. H., Tasnim, T., Munir, J.

DOI: 10.36566/ijhsrd/Vol3.Iss2/87

https://ijhsrd.com/index.php/ijhsrd

e- ISSN: 2715-4718

results of statistical tests using the Chi Square test at $\mathrm{p}$-value $0.000 \leq 0.05$, meaning that there is a significant relationship between infrastructure and the level of

Table 1. Distribution of Respondents by Accreditation

Level of Public health center in Konawe District

\begin{tabular}{|c|c|c|c|}
\hline \multirow{2}{*}{ No. } & \multirow{2}{*}{ Accreditation Level } & \multicolumn{2}{|c|}{ Amount } \\
\cline { 3 - 4 } & Non Accreditation & 38 & n \\
\hline 1 & Basic & 44 & 27.3 \\
\hline 2 & Middle & 57 & 31.6 \\
\hline 3 & Amount & 139 & 41.0 \\
\hline & \multicolumn{2}{|c|}{} \\
\hline
\end{tabular}

Table 2. Relationship between Resources and Accreditation Level of Public health center in Konawe District

\begin{tabular}{|c|c|c|c|c|c|c|c|}
\hline \multirow{3}{*}{ Accreditation Level } & \multicolumn{4}{|c|}{ Resources } & \multirow{2}{*}{\multicolumn{2}{|c|}{ Amount }} & \multirow{3}{*}{ Statistics test } \\
\hline & \multicolumn{2}{|c|}{ Adequate } & \multicolumn{2}{|c|}{ Inadequate } & & & \\
\hline & $\mathbf{n}$ & $\%$ & $\mathbf{n}$ & $\%$ & $\mathbf{n}$ & $\%$ & \\
\hline Non Accreditation & 0 & 0 & 38 & 27.3 & 38 & 27.3 & \multirow{4}{*}{$P-$ Value $=0,000$} \\
\hline Basic & 0 & 0 & 44 & 31.7 & 44 & 31.7 & \\
\hline Middle & 24 & 17.2 & 33 & 23.7 & 57 & 41 & \\
\hline Amount & 24 & & 115 & & 139 & 100 & \\
\hline
\end{tabular}

Table 3. Relationship Infrastructure With Accreditation

Level of Public health center in Konawe District

\begin{tabular}{|c|c|c|c|c|c|c|c|}
\hline \multirow{3}{*}{ Accreditation Level } & \multicolumn{4}{|c|}{ Infrastructure } & \multirow{2}{*}{\multicolumn{2}{|c|}{ Amount }} & \multirow{3}{*}{ Statistics test } \\
\hline & \multicolumn{2}{|c|}{ Adequate } & \multicolumn{2}{|c|}{ Inadequate } & & & \\
\hline & $\mathbf{n}$ & $\%$ & $\mathbf{n}$ & $\%$ & $\mathbf{n}$ & $\%$ & \\
\hline Non Accreditation & 0 & 0 & 38 & 27.3 & 38 & 27.3 & \multirow{4}{*}{$P$-Value $=0,000$} \\
\hline Basic & 0 & 0 & 44 & 31.7 & 44 & 31.7 & \\
\hline Middle & 34 & 24.4 & 23 & 16.5 & 57 & 41 & \\
\hline Amount & 34 & & 105 & & 139 & 100 & \\
\hline
\end{tabular}

Table 4. Relationship between Quality of Service and Accreditation Level of Public health center in Konawe District

\begin{tabular}{|c|c|c|c|c|c|c|c|}
\hline \multirow{3}{*}{ Accreditation Level } & \multicolumn{4}{|c|}{ Quality of service } & \multirow{2}{*}{\multicolumn{2}{|c|}{ Amount }} & \multirow{3}{*}{ Statistics test } \\
\hline & \multicolumn{2}{|c|}{ Quality } & \multicolumn{2}{|c|}{$\begin{array}{l}\text { Not good } \\
\text { quality }\end{array}$} & & & \\
\hline & $\mathbf{n}$ & $\%$ & $\mathbf{n}$ & $\%$ & $\mathbf{n}$ & $\%$ & \\
\hline Non Accreditation & 33 & 23.7 & 5 & 3.5 & 38 & 27.3 & \multirow{4}{*}{$\begin{array}{l}P-\text { Value }= \\
0.005\end{array}$} \\
\hline Basic & 42 & 30.2 & 2 & 1.4 & 44 & 31.7 & \\
\hline Middle & 57 & 41 & 0 & 0 & 57 & 41 & \\
\hline Amount & 132 & & 7 & & 139 & 100 & \\
\hline
\end{tabular}

Indonesian Journal Of Health Sciences Research and Development 


\section{DISCUSSION}

\section{Relationship between Resources Health Centre Accreditation Level}

To realize the success of the Healthy Indonesia Program with a Family Approach, various health efforts are carried out which are supported, among others, adequate and equitable health human resources according to their needs(5).

The results showed that there was a relationship between resources and the level of accreditation at the health centres in Konawe Regency, where the p-value was $0.000<0.05$. This is because the accreditation system will encourage resources according to the standards in each accredited health centre. This is in line with the research conducted(6) that the state of resources for the preparation of Public health center accreditation is not entirely supportive because there are still some shortcomings in terms of staff quantity and quality.

In this study it was also known that there were 38 respondents $(27.3 \%)$ from health centres with non-accreditation levels and 44 respondents (31.6\%) from basic accreditation health centres and 33 respondents $(23.7 \%)$ from public health centre with intermediate accreditation levels. declared insufficient resources. This is because several health centres in Konawe district health workers who are medical laboratory experts, dental nurses, general practitioners, dentists, and other health workers have not been fulfilled and 24 respondents $(17.2 \%)$ stated their resources This has been fulfilled because in several Public health centre with intermediate accreditation levels for health workers, it is sufficient.
The Relationship between Infrastructure and Public Health Centre Accreditation Levels

Infrastructure is a potential factor that is very important in determining the direction and future of the development of a health centre, because development will not be successful and run well without adequate infrastructure support (7).

The results showed that there was a significant relationship between infrastructure and the level of accreditation of health centre in Konawe Regency, Southeast Sulawesi Province, where the pvalue was $0.000<0.05$. So that the results of this study can prove that infrastructure has something to do with the level of accreditation. This research is in line with research conducted by(8)Public health centre facilities and infrastructure. Completeness of facilities and infrastructure as a basis for providing standardized services is not yet fully available. The accreditation assessment will be based on the facilities available to provide services.

The results of this study also showed that 38 respondents $(27.3 \%)$ stated that there were 38 respondents $(27.3 \%)$ who stated that the facilities and infrastructure were inadequate. Of the Public health center with a basic accreditation level, 44 respondents $(31.6 \%)$ stated that they were inadequate. Meanwhile, from Public health center with intermediate accreditation level, 23 respondents $(16.5 \%)$ stated that the facilities and infrastructure were inadequate. This is because not all of the infrastructure facilities at the health centre are in accordance with the standards of the minister of health, some health centres in Konawe district are not equipped with fire protection, lightning protection, medical gas, solid and liquid waste disposal, and incomplete medical equipment according to the standards of the minister of health and from health centres with intermediate accreditation levels there were 34 respondents 24 . 
Relationship between Service Quality and Health Center Accreditation Level

The quality of health service is the perfection of health services organized in accordance with the code of ethics and service standards set, so as to lead to satisfaction for every patient(9).

The results showed that there was a relationship between service quality and the level of accreditation of health centres in Konawe Regency, where the p-value was $0.005<0.05$. This is because the accreditation system will encourage the quality of service according to the standards in each accredited health centre. This is in line with the research conducted(10) in Simalungun Regency which states that service quality has a significant relationship with accreditation status ( $\mathrm{p}<0.05)(11)$.

In this study it was also known that there were 33 respondents $(23.7 \%)$ from non-accredited Public health centre, 42 respondents $(30.2 \%)$ from basic accreditation Public health centre and 57 respondents (41\%) from Public health centre with intermediate accreditation level who stated Public health centre services quality. This is because a number of things include that most of the patients who became respondents had provided services with SOPs. Officers are able to understand the patient's needs, and are able to provide motivational encouragement to patient problems. Officers always treat patients well and do not differentiate between patients in providing services.

And from health centres with nonaccreditation, there were 5 respondents (3.5\%) who stated that the quality of service was not good quality. From Public health centre with basic accreditation level, there were 2 respondents $(1.4 \%)$ who stated that the service was not of good quality. This is because the accreditation of Public health centre is not only based on the quality of service, but is supported by various other aspects that have been established by
Permenkes No. 46 of 2015 concerning Public health centre Accreditation Standards consisting of 3 parts and 9 chapters.

\section{CONCLUSION}

From the results of research conducted in Konawe District where the resources, infrastructure, and service quality are related to the accreditation level of the Public health centre in Konawe Regency. So it is hoped that the Health Office will conduct monitoring and evaluation, supervision of all Public health centre and teamwork in implementing Public health centre accreditation.

\section{REFERENCES}

1. Putri W, Yuliyatni PCD, Aryani K, Sari K, Sawitri A. Basics of Community Health Centers (Puskesmas). Management and Community Health Center Program Briefing Module. 2017: 1-12.

2. Jayadipraja EA, Prasetya F, Azlimin A, Mando WOSY. Family clean and healthy living behavior and its determinant factors in the village of Labunia, Regency of Muna, Southeast Sulawesi Province of Indonesia. Public Health of Indonesia. 2018; 4 (1): 39-45.

3. Herdiyanto H, Widayat W, Widiastuti N.Implementation of Employee Performance Appraisal of the Regional Technical Implementation Unit of the Buluspesantren Ii Community Health Center, Buluspesantren District, Kebumen Regency: STIE Widya Wiwaha; 2019.

4. Konawe District Health Office. Accreditation of Public health center in Konawe Regency. Southeast Sulawesi2020.

5. Idris HA. Introduction to human resource economics: Deepublish; 2016.

6. Koesoemahardja NF, Suparwati A, Arso SP. Analysis of basic accreditation 
readiness of Mangkang Health Center in Semarang City. Journal of Public Health (Undip). 2016; 4 (4): 94-103.

7. Sulistinah A, Witcahyo E, Sandra C. Readiness Review of Management Administration Working Group Accreditation Documents at Upt. Jelbuk Public health center Health Office Jember Regency (Study of Preparation on Accreditation Document for Administration Management at Jelbuk Primary Health Center Jember). Health Library. 2017; 5 (3): 580-7.

8. Susilawati Susilawati S. Overview of Health Center Accreditation Implementation in the District / City of North Sumatra Province in 2016. JUMANTIK (Scientific Journal of Health Research). 2017; 2 (2): 89-99.

9. Riyadi R. Quality of health services for participants in the national health insurance program at Public health center, Kembangan District, West Jakarta. 2015.

10. Marlina S, Silalahi N, Insani SD, Tarigan HN, Sitorus FE. Relationship between Public health center Accreditation Status and Service Quality in Simalungun Regency. Journal of Medical Nursing Research. 2020; 2 (2): 45-53.

11. Batubara S, Napitupulu LR, Kasim F, Manalu ED, Jauhari W. Relationship between Public health center Accreditation Status and Service Quality in Simalungun Regency. Wahana Inovasi: UISU Journal of Research and Community Service. 2019; 8 (1). MCH. 2017.

6. Southeast Sulawesi Provincial Health Office. Immunization Coverage. Southeast Sulawesi2019.

7. Sari DD. Maternal factors associated with basic infant immunization in the working area of the Korpri Public Health Center, Sub-district of Kecamatan Kota,
Bandarlampung.

Http://digilib.unila.ac.id; 2018.

8. Alamsyah A, Rasyid Z, Ikhtiaruddin I, Wahyudi W. Determinants of Measles in Toddlers in the Work Area of the UPTD Puskesmas Harapan Raya, Pekanbaru City. Endurance Journal: Scientific Study of Health Problems. 2020; 5 (2): 202-15.

9. Mackey A, Gass SM. Second language research: Methodology and design: Routledge; 2015.

10. Indonesian KR. Indonesia Health Profile 2014. Jakarta: Ministry of Health RI. 2015: 1-382.

11. Jamaluddin J. Effectiveness of Binahong Leaf Extract (Anredera cordifolia) and Earring (Acalypha indica) as Antibacterial Staphylococcus aureus (As an Alternative Material for Developing Practicum Instructions for Kingdom Monera SMA Class X, Odd Semester): UIN Raden Intan Lampung; 2017.

12. Raidanti D. Relationship of Accessibility, Support of Health Workers and Perceptions of the Implementation of Immunization for Pre-Marriage Family at Sukamulya Health Center, Sukamulya District, Kab. Tangerang in 2017. Pomegranate Health Scientific Journal. 2019; 3 (1): 52-65.

13. Indriani D. Fatwa Mui No 04 of 2016 concerning the Legalization of Immunization Vaccines for Toddlers in Islamic Law Perspective. Https://dspace.uii.ac.id; 2018. 